\title{
Investigating surface movements of debris-covered Miage glacier, Western Italian Alps, using dendroglaciological analysis
}

\author{
Manuela PELFINI, Maurizio SANTILLI, Giovanni LEONELLI, Mauro BOZZONI \\ Department of 'Ardito Desio' Earth Sciences, University of Milan, Via Mangiagalli 34, I-20133 Milan, Italy \\ E-mail: manuela.pelfini@unimi.it
}

\begin{abstract}
Dendroglaciological analysis of supraglacial trees represents an example of applied dendrogeomorphological methods in reconstructing glacier variations. Supraglacial trees react to glacier ice and debris movement, assuming typical shapes with modified radial growth. In this paper, based on treering analysis of Larix decidua Mill., we investigate the relationship between the distribution and growth of trees located on the most famous and representative debris-covered glacier in the Italian Alps (Miage glacier, Valle d'Aosta) and the superficial movements of ice and debris in the lower part of the tongue. Different growth anomalies (e.g. pointer years, compression wood, abrupt growth changes) were identified and dated. Three reference tree-ring chronologies based on undisturbed larches growing outside the glacier were constructed for comparison with tree-ring data from supraglacial trees. The oldest sampled trees colonized the glacier surface just before 1960 . The simultaneous presence of different disturbance indicators occurred mainly between 1984 and 1990 on the southern lobe and during the period 1989-93 on the northern glacier lobe. These results fit with glaciological data documenting volume and surface-level variations in the same period.
\end{abstract}

\section{INTRODUCTION}

The importance of trees as an instrument for recording environmental and climatic changes is well known and well documented (e.g. Fritts, 1976; Schweingruber, 1996) since trees respond with variations in tree-ring growth and tree morphology. Trees growing near glacierized areas progressively record the climate variations responsible for glacier fluctuations. In their advancing phases, glaciers can also directly damage trees growing in the foreland. Buried and damaged trees allow the reconstruction of glacier history, especially of the more recent Little Ice Age fluctuations (e.g. Luckman, 1996, 2000; Holzhauser and Zumbuhl, 1999; Pelfini, 1999, 2003). Trees close to the glacier allow the study of surge advancing phases (Kaiser, 1993) and the reconstruction of ice movement direction by means of buried and deformed trunks (e.g. Fleisher and others, 2006). Moreover, as a valuable proxy of climate, tree rings also allow dendrochronologically based mass-balance reconstructions (e.g. Nicolussi, 1994; Watson and Luckman, 2004; Larocque and Smith, 2005).

On debris-covered glaciers, vegetation can colonize the surface when the debris is thick enough to retard ablation. In most cases, vegetation cover is comprised of grasses, sedges and alpine plants, but in temperate regions trees can also establish (Benn and Evans, 1998). Dendroglaciological analysis of supraglacial trees is an example of applied dendro-geomorphological methods for reconstructing glacier variations. Supraglacial trees react to glacier pushing and to vertical movements related to freezing and melting processes, assuming characteristic shapes and recording growth disturbances in tree-ring morphology.

This paper aims to improve our understanding of glacier dynamics by studying supraglacial trees. Using tree-ring analysis, we investigate the relationship between the development and the distribution of trees located on a debris-covered glacier (Miage glacier, western Italian Alps), their growth anomalies and the superficial movements of ice and debris in the lower part of the tongue.

\section{THE STUDY AREA}

Miage glacier $\left(45^{\circ} 47^{\prime} \mathrm{N}, 6^{\circ} 52^{\prime} \mathrm{E}\right)$ is the most famous and representative debris-covered glacier in the Italian Alps. With a surface area of about $11 \mathrm{~km}^{2}$ (Diolaiuti and others, 2005a) and a length of $6 \mathrm{~km}$, Miage glacier is the third largest Italian glacier; it drains the southwest slope of Mont Blanc in Val Veny, Valle d'Aosta, (Figs 1 and 2). The continuous debris covering of the ablation tongue $\left(2.9 \mathrm{~km}^{2}\right.$ wide), starts at an altitude of $\sim 2400 \mathrm{~m}$, initially with medial moraines, and continues across the entire surface below, mainly due to rockfalls (Pelfini and others, 2005).

Using old descriptions, (e.g. Saussure, 1774, 1786; Baretti, 1880; Sacco, 1917), Deline (2002) reconstructed the clean-glacier/debris-covered-glacier transformation at the end of the 19th century. The Miage morainic amphitheatre has also allowed reconstruction of the neoglacial history of the glacier advances dated to the early neoglacial, end of Göschener I, end of Göschener II and the Little Ice Age (Deline and Orombelli, 2005).

Much glaciological research was conducted on this glacier, particularly focusing on calving processes at Miage lake, in order to estimate volumetric ice-cliff loss, surface velocity (Diolaiuti and others, 2005a) and surface elevation changes (Thomson and others, 2000). However, less attention was paid to the supraglacial vegetation that adds an important ecological value to Miage glacier when it is proposed as a glacial geomorphosite (Pelfini and Smiraglia, 2003; Panizza, 2005; Pelfini and others, 2005). A geomorphosite is a landform with particular and significant attributes which may be equated with a component of the cultural heritage of a given territory (Panizza, 2001; Coratza and Giusti, 2005; Diolaiuti and others, 2005b). Potential attributes contributing value to a landform are scientific, cultural, socio-economic and scenic (Panizza and Piacente, 1989).

The glacier terminus is characterized by two main lobes and a small intermediary lobe (Figs 1 and 2a). The presence of supraglacial debris allows vegetation development in 


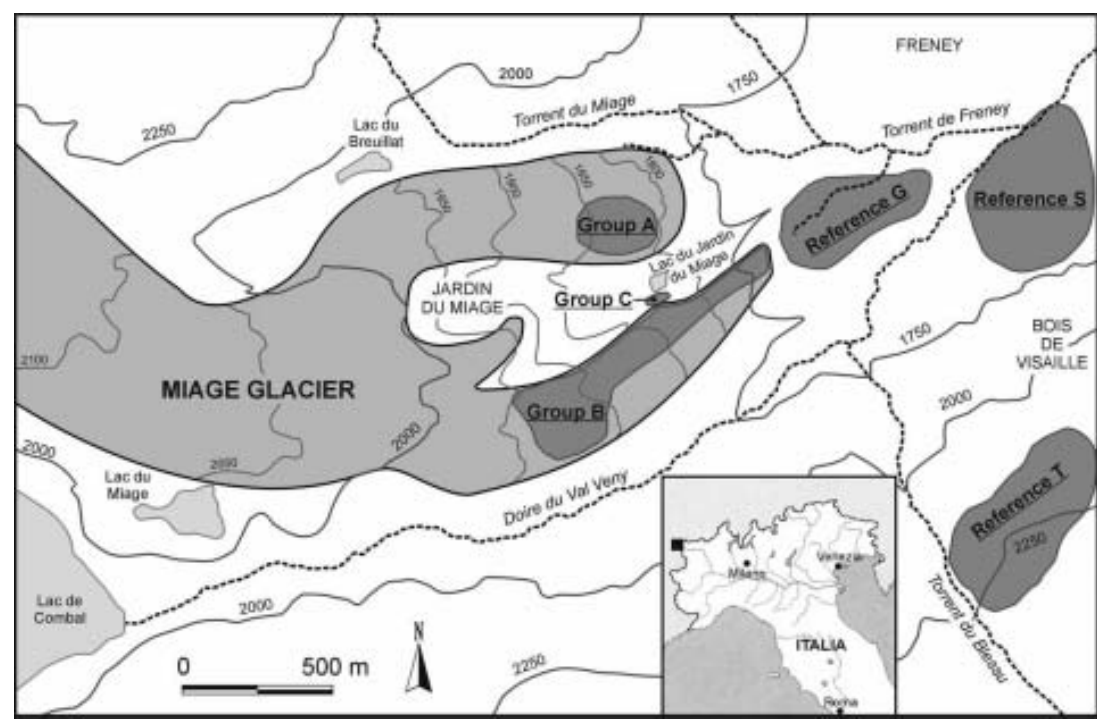

Fig. 1. Map of the study area and location of the different groups of supraglacial and reference trees analyzed.

relation to the thickness, stability, morphometric and chemical/physical characteristics of the debris itself. The southern lobe appears to be more stable despite the fact that debris movement can be observed by comparing photographs taken only 1 year apart (Pelfini and others, 2005). For the upper part, Deline (2002) estimated an average velocity, obtained by similarities with the Mer de Glace, of $55 \mathrm{~m} \mathrm{a}^{-1}$. He also described the 1945 rockfall deposit path on the glacier which was found about 3100 m further down-valley in 1997; this would give a surface velocity of $\sim 60 \mathrm{~m} \mathrm{a}^{-1}(3100 \mathrm{~m}$ in 52 years). Direct measurements on the glacier surface, revealed an average velocity for the same sector of 50-70 $\mathrm{m} \mathrm{a}^{-1}$ (Diolaiuti and others, 2005a). At the area close to Miage lake, the surface velocity reaches peaks of $76 \mathrm{~m} \mathrm{a}^{-1}$, while in the median area of the glacier, towards the opposite margin at the same altitude, it is $45 \mathrm{~m} \mathrm{a}^{-1}$ (values of $38-51 \mathrm{~m} \mathrm{a}^{-1}$ ). This velocity then reduces notably towards the glacier terminus. The surface velocity is $0-4 \mathrm{~m} \mathrm{a}^{-1}$ near the front, $\sim 4-10 \mathrm{~m} \mathrm{a}^{-1}$ in the medial portion of the southern lobe and reaches $15-22 \mathrm{~m} \mathrm{a}^{-1}$ close to the southern-lobe origin (data reconstructed from field surveys of Lesca (1974) relating to the period 1965-71) (Diolaiuti and others, 2005a).

The debris-covered glacier surface on the frontal lobes appears undulating in a variable way, owing to the presence of niches, depression zones and channels delineating a morphology mostly created by differential ablation. The surface is covered by a layer of debris which grows progressively thicker in the down-valley direction, rarely exceeding $2 \mathrm{~m}$ (Deline, 2002). In summer 2005 the debris thickness at the internal margin of the southern lobe of the glacier varied between 40 and $110 \mathrm{~cm}$, with an average of $90 \mathrm{~cm}$ (Fig. 2b).

Transformation from a clean glacier to a debris-covered glacier has modified the behaviour of Miage glacier with respect to other alpine glaciers which are currently distant from their frontal moraines, deposited at the Little Ice Age maximum. In fact, mass variations are translated into thickness changes in this glacier (and also in the lower snout sector where trees grow) which tends to swell or contract with the passage of kinematic waves instead of moving frontally (Smiraglia and others, 2000). For example, Miage glacier experienced a general thickening in the upper part of the tongue and a lowering at the terminus between 1967 and 1975, followed by a net volume increase in the lower part of the tongue during the period 1975-99 (Thomson and others, 2000). Our dendroglaciological analysis was conducted on the frontal lobes of Miage glacier, the only glacier portion where trees grow.

\section{SUPRAGLACIAL AND PERIGLACIAL VEGETATION}

The lower part of the Miage glacier tongue is partially colonized by trees (European larch, Larix decidua Mill., and Norway spruce, Picea abies Karst), shrubs (Salix spp.) and herbaceous vegetation. Supraglacial tree vegetation is dominated by scattered larches, some as high as 3-4 m, while only a few spruce, up to some decimetres tall, are present. On the southern lobe, the vegetation is more developed than on the northern lobe.

Trees growing in the forefield and on the north-facing valley slope are larger and taller, forming an open-canopy forest cover dominated by larches. A comparison performed during preliminary studies on a subsample of trees showed that supraglacial trees were $\sim 30 \%$ shorter than trees growing outside the glacier (Pelfini and others, 2005). This difference in tree growth could be related to soil nutrients, water availability and/or soil temperature (Körner and Hoch, 2006).

On the glacier, shrubs and herbaceous vegetation are mostly concentrated in small niches along the glacier tongue, while vegetation outside the glacier is rich and continuous. In some morphological situations such as hollows, depressions or niches, local conditions facilitate better growth of trees. In these situations, more complex vegetation patterns are found, along with a higher population density. In other cases, the bases of some trees are covered by debris or show exposed roots, revealing the continuous movement of clasts and blocks. Some trees bear cones, indicating their potential reproduction capacity above the glacier, suggesting that colonization does not only occur by seeds from outside.

Trees record annual events within the tree rings and in the tree-stem morphology, permitting recognition of the glacier evolution. Variations in tree morphology include bent, deformed, twisted, bifurcated, stunted and bow-shaped 
stems (Fig. 2c), tree-ring width and eccentricity, and the production of compression wood. The ice sliding downvalley, the transmission of kinematic waves, glacio-karst phenomena and debris-cover instability are precisely recorded by the vegetation moving down-valley, following the glacier movement (Richter and others, 2004).

\section{MATERIALS AND METHODS}

\section{Sampling}

Many field surveys were carried out in order to map the tree distribution on the glacier surface and to take cores. This research concerns only the European larch which is the most abundant species.

For sampling, we used a Pressler's increment borer with a $5 \mathrm{~mm}$ diameter and variable length in relation to tree size. Each sampled tree was located on a topographic map (enlargements from scale $1: 10000)$. For each tree we collected the following data: height, diameter, morphological characteristics, altitude and the conditions of the surrounding surface.

Fifty-two larches were sampled on the northern lobe (11 samples, group A in Fig. 1) and the southern lobe (41 samples, group B in Fig. 1); we looked for the larger, and presumably older, trees in each sampling area. Cores were taken near the stem base, $\sim 10-15 \mathrm{~cm}$ above the surface, extracting a single sample per tree, crossing the stem through the pith. Drilling was preferably executed in the local upslope-downslope direction, but was also conditioned by the presence of branches starting from the stem base and the possibility of turning the borer. This direction allowed us to include compression wood in our samples, which is a reaction wood typically developed on the downhill sides of the tilted stems of conifers to recover their vertical position (Timell, 1986). Using the same methods as before, nine larches were also sampled on the inner lateral moraine since they were clearly bent by the glacier and had thus developed compression wood (group C in Fig. 1).

Three reference chronologies were constructed, based on undisturbed larches growing outside the glacier, for comparison with tree-ring data from supraglacial trees. Tree growth outside the glacier is not directly influenced by glacier fluctuations since the sampling areas were not covered by the glacier in recent centuries (Deline, 2002). Therefore, the three reference chronologies can be used to identify growth anomalies induced in supraglacial trees by glacier surface movements. Climate is common to all trees in the valley, outside and on the glacier, influencing tree-ring growth mostly at the highest altitudes. Larch is known to be sensitive to climate, and useful for dendroclimatology (e.g. Hüsken and Schirmer, 1993; Carrer and Urbinati, 2006). Forty-six larches which grew in undisturbed conditions were sampled outside the glacier in the proglacial area. We chose only dominant trees with vertical stems, without disturbance in the crown, and similar in age and size to the supraglacial trees. The sample sites were chosen considering two types of substrata: the first group of trees grows on gravel and debris substratum similar to the glacier surface (reference $G$ in Fig. 1); the second grows on developed soil without limiting edaphic conditions (reference $S$ in Fig. 1).

We also used 11 tree-ring growth series constructed from previous research (unpublished data) to build another

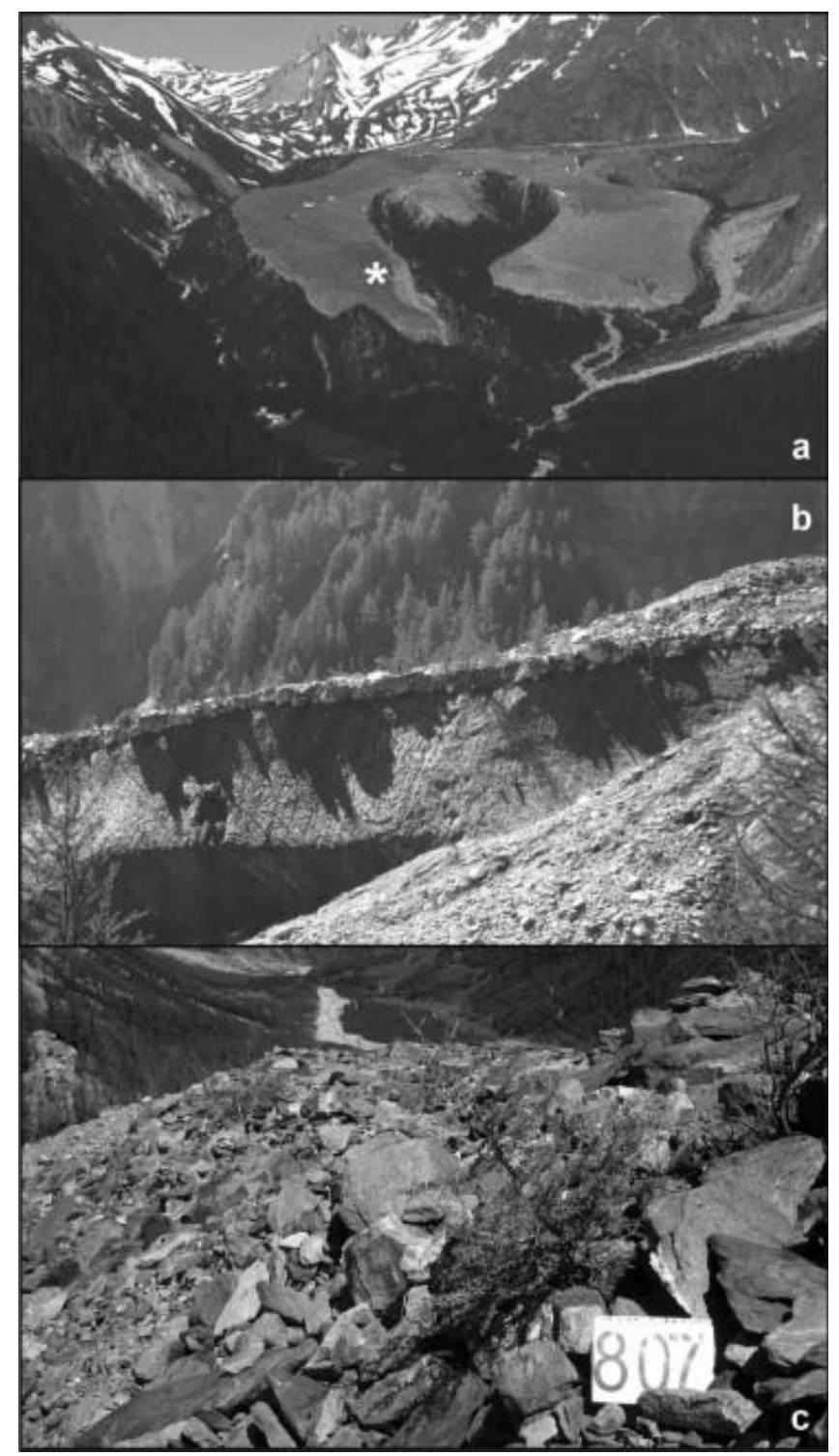

Fig. 2. (a) Panoramic view of the Miage glacier tongue in 2004; (b) detail of trees (larches) growing on the debris above the ice cliff in 2004 (the asterisk in (a) indicates the location of (b)); and (c) a tilted supraglacial tree in 2005.

reference chronology (reference $\mathrm{T}$ in Fig. 1). These growth series are from larches growing at the tree line in undisturbed locations in the valley (north-facing slope), close to Miage glacier. These trees are older and have grown at a higher altitude than those of the references $G$ and $S$, and thus contain a stronger climatic signal (Carrer and Urbinati, 2004; Frank and Esper, 2005).

The samples were prepared and polished with sandpaper for microscope analysis and measured following standard procedures (Schweingruber, 1988).

\section{Analysis}

Tree rings were counted in each sample, checking for the same number of rings on both cores (or rays) of a tree. The cambial age of each sample was determined by counting the number of annual rings (Schweingruber, 1988). Missing rings in the samples without pith were estimated according to Jozsa (1988). The obtained age is a minimum, since it is necessary to add the years between the soil surface and the 


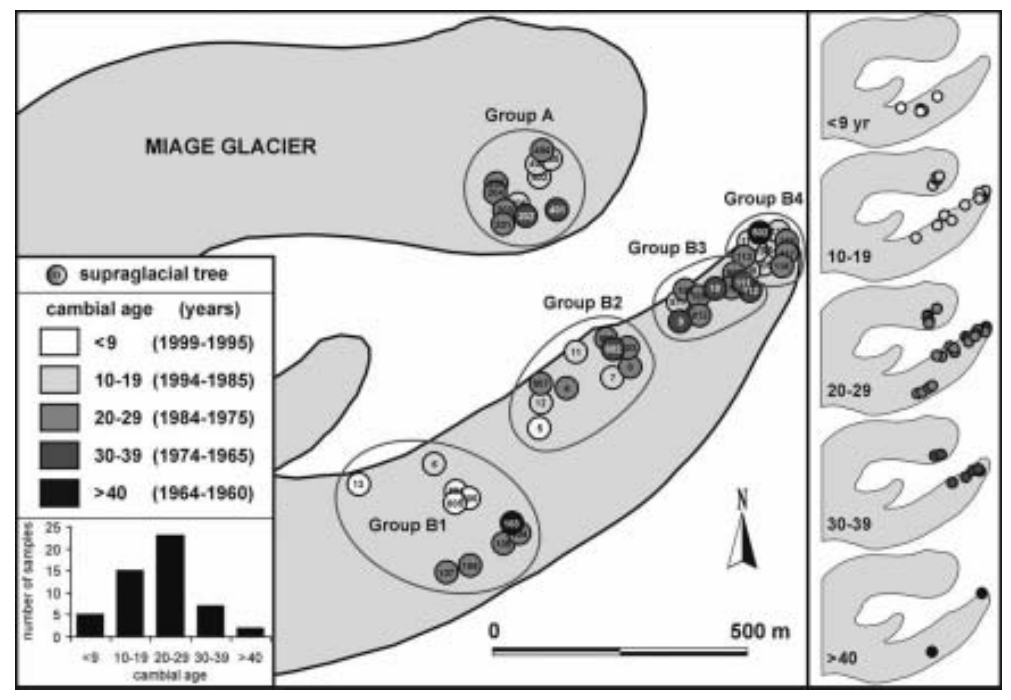

Fig. 3. Location of the sampled supraglacial trees and their cambial age. The results refer only to the sampled trees and not to the whole supraglacial tree population.

sampling point $(\sim 10-15 \mathrm{~cm})$ to determine the total age of a tree. The number of missing years depends on the species, the sampling site and the environmental conditions (Gutsell and Johnson, 2002).

Tree-ring widths were measured and single growth curves were built for each sample using the LINTAB-TSAP (Rinn, 1996) and WINDENDRO image-analysis systems. Crossdating was performed both visually on screen and statistically using TSAP and COFECHA software, respectively (Holmes, 1983). Each reference chronology was constructed by averaging synchronized tree-ring series after eliminating those series presenting a low correlation coefficient $(<0.2)$ with the mean curve.

By comparing single growth curves of supraglacial trees with reference chronologies ( $T, G$ and $S$ ) it was possible to check the correct dating of each ring. The comparison was performed both with the longest chronology (reference T) and with references $G$ and $S$ to compare supraglacial trees with trees of similar age (i.e. with similar growth trends) and of similar substrata (reference G).

In order to identify the temporal distribution of the growth disturbances in supraglacial trees, possibly induced by debris instability and glacier movements, we adopted two main approaches: a tree-ring growth series analysis performed on ring-width measurements (pointer years and abrupt growth changes) and skeleton plots made by a visual assessment of samples (event years). In detail, we considered:

\section{Tree-ring growth series analysis}

1. Pointer years, according to Huber and Giertz-Siebenlist (1969). Pointer years are defined as years when more than $75 \%$ of the samples show the same interval trend (positive indicates growth release, negative indicates growth suppression). They were considered as indicators of glacier disturbance when not present in the reference chronologies. The trees on the southern lobe (group B) were divided into a further four groups (B1-B4) according to their position along the lobe (Fig. 3).

2. Abrupt growth changes. We calculated the percentage growth variation with respect to the mean of the four previous years, for each year. Threshold values of positive or negative variations were fixed at 40\%, 55\% and 70\% (Schweingruber and others, 1991; Rolland and others, 2001). To compare abrupt growth changes among the trees belonging to the two groups (A and $\mathrm{B}$ ) and to the three reference chronologies $(G, S$ and $T)$, we considered the periods defined by the presence of at least $50 \%$ of total cores per group with the period (19602003) covered by the tree-ring series of the supraglacial trees. Since the sample size of the five groups is different and varies over time, we calculated the mean percentage of cores per year presenting an abrupt growth change (for each group of cores and for each interval of growth variation).

Both pointer years and abrupt growth changes indicate rapid changes in environmental conditions.

\section{Skeleton plots}

Growth anomalies were identified by visual analysis of the samples. These represent event years, defined as years characterized by conspicuous features observed visually in the assessment of single tree-ring series (Schweingruber and others, 1990). In this category we considered different types of growth anomalies: single very narrow or wide tree rings, missing rings, rings with many resin ducts, eccentricity variations, abrupt growth changes (here defined by ring width at least $40 \%$ smaller or $160 \%$ wider than that of the preceding 4 years, lasting for more than 4 years) (Schweingruber, 1986; Z'Graggen, 1987) and compression wood. Because the production of compression wood can continue for more than 1 year, we considered only the first ring in which it is present, corresponding to the instability occurrence. This indicator was considered more important than the others because of its clear dependence on substrate instability (e.g. surface glacier movements).

The considered event years represent growth disturbance: for example single, very wide rings with respect to the same ring on the opposite side of the stem indicate eccentric growth induced by substratum instability. Moreover, since anomalous rings can also be formed in the wake of different kinds of damage (e.g. wounds caused by rockfall, insect outbreaks, animal browsing), dendrochronological analysis 


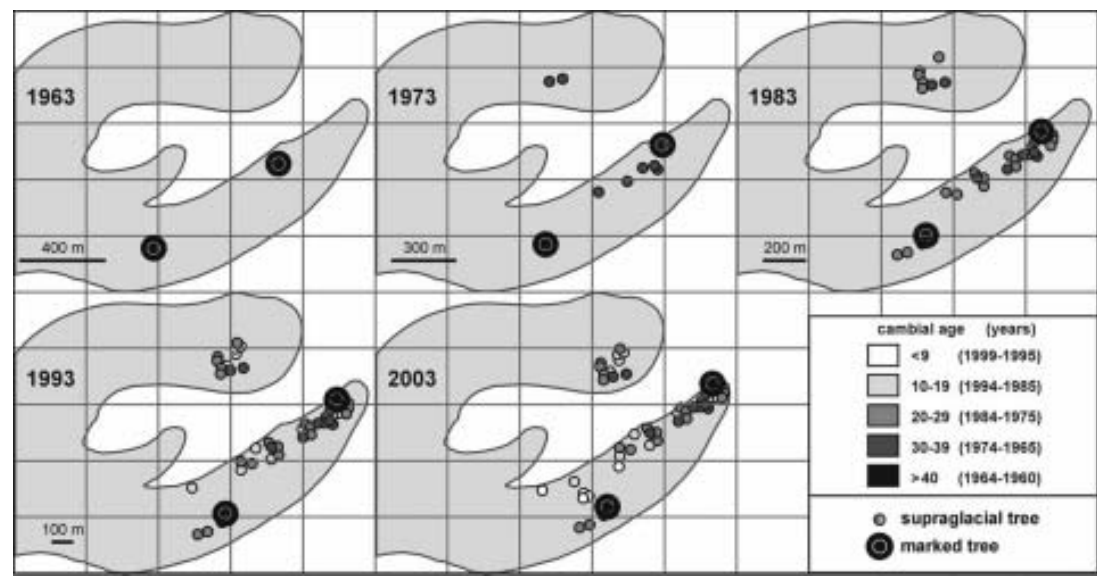

Fig. 4. Reconstructed position of trees on the glacier every 10 years assuming a mean velocity of $10 \mathrm{~m} \mathrm{a}^{-1}$. This value was determined as a mean of the velocity data reported in Diolaiuti and others (2005a). The two oldest trees (referring to their cambial age) are marked with larger circles.

must be conducted together with geomorphological and glaciological investigations in order to better define the causes of tree damage and growth disturbances.

We considered all the possible tree-ring indicators to identify, date and localize possible movements of the glacier and/or debris cover. In addition, we considered the years which presented different signals at the same time as the most reliable. We also defined the yearly spatial distribution of the event years of the supraglacial trees during the period 1960-2003 to examine whether it was possible to identify the areas of the glacier tongue with particularly unstable substrates for certain years.

Previous studies relating to glacier dynamics and photointerpretation were analyzed to interpret dendrochronological data and to correlate them with the glacier dynamics. In detail, mean superficial velocity data of the glacier tongue $\left(\sim 10 \mathrm{~m} \mathrm{a}^{-1}\right)$ (derived from Diolaiuti and others, 2005a) were used to reconstruct the location of the supraglacial trees during their lives. Surface-elevation changes (Thomson and others, 2000) and aerial photos (Giardino and others, 2001) were used to correlate the areas of maximum glacier deformation with the occurrence of tree growth disturbance.

\section{RESUITS}

In all, 89 single growth curves (one or two per tree) and three reference tree-ring chronologies were built. Growth curves from supraglacial trees show great individual variability with respect to the reference chronologies, and in relation to the local conditions. Tree cambial age, and temporal and spatial distribution of years with growth disturbances, provide information about the glacier dynamics.

\section{Tree age}

In the southern lobe, the cambial age of the trees tends to increase down-valley (Fig. 3), even if the altitude difference between the glacier front and the origin of the southern lobe is only about $200 \mathrm{~m}$. The two oldest sampled trees (class age $>40$ years) colonized the glacier surface before 1960. Class age 30-39 years is located in the lower part of the tongue (seven trees). The most common class is 20-29 years, with trees located on both the lobes (23 trees) near the internal margin. Upward and towards the internal margin of the southern lobe the most common age classes are 10-19 years (15 trees) and $<9$ years ( 5 trees).

The youngest trees are located in the upper part of the southern lobe (Fig. 3) but mainly in niches characterized by fine debris. Here, where the debris thickness is very shallow and unstable, there are no trees. Moreover, many swallow holes are present, probably induced by differential ablation and a higher superficial velocity (Diolaiuti and others, 2005a).

Tree colonization is more intense on the internal margin of the southern lobe. However, this is the present situation and may differ from the time when the trees germinated. In fact, if we use the velocity vectors reported by Diolaiuti and others (2005a), trees were probably located in the central part of the lobe at the beginning of their lives. Considering a mean surface velocity of $10 \mathrm{~m} \mathrm{a}^{-1}$, the oldest tree (sample 103 in Fig. 3, marked in Fig. 4) germinated almost $400 \mathrm{~m}$ up-glacier. Nevertheless, we have not recently found young trees in that vicinity.

\section{Reference chronologies}

Reference chronology T, for Val Veny, is 395 years long (1603-1997); reference chronology $S$ covers the period 1821-2003 and is composed of 34 samples (most are younger than 40 years); and reference chronology G covers the time interval 1904-2003 and is built from 30 samples.

As the larches composing the reference chronologies do not manifest any disturbance in the crown or stem, their growth variations are highly related to the general climatic conditions. Even if the reference chronology trends are also influenced by the number of samples and by their age, the three curves developed use only the 1960-2003 segment, because the first measurable ring in the supraglacial trees dates back to 1960 (Fig. 5a).

\section{Temporal distribution of years with growth disturbances}

\section{Pointer years, according to Huber and Giertz-Siebenlist (1969)}

Fourteen pointer years were identified in the mean reference chronology (mean of the reference chronologies T, S and G) during the period 1960-2003 (Fig. 5a). These pointer years mainly refer to climate influence on tree growth and they 


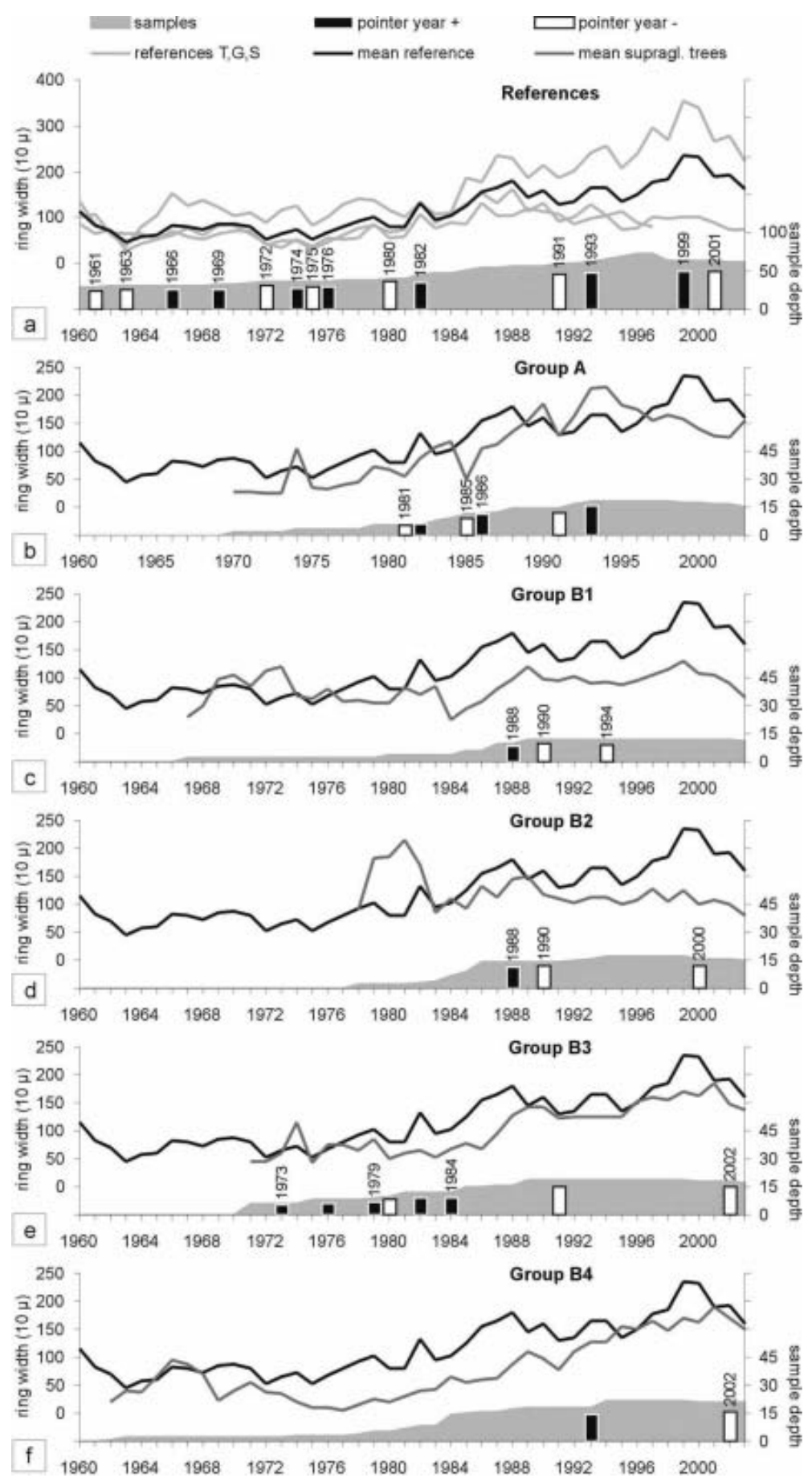

Fig. 5. Pointer years according to Huber and Giertz-Siebenlist (1969) (more than 75\% of samples with positive or negative variations in the same years) identified in the reference chronologies and in the supraglacial trees. Only the years not present in the reference (a) are reported in $(b-f)$.

were therefore excluded from pointer years found in supraglacial trees.

Pointer years in the northern-lobe trees (group A, Fig. 3) were identified as 1981, 1985 (negative) and 1986 (positive) (Fig. 5b). The opposite trend of the mean chronology of the northern-lobe trees outlines a negative pointer year in 1985 in contrast with the increasing trend in the mean reference chronology.

Pointer years identified for the supraglacial trees of the southern lobe are divided into four groups (groups B1-B4, Fig. 3). Years not present in the mean reference chronology are 1973, 1979, 1984, 1988, 1990, 1994, 2000 and 2002.
The comparison shows some significant negative pointer years with the opposite trend of the mean reference chronology (e.g. 1990 (Fig. 5c and d) and 2002 (Fig. 5e and $f)$ ).

\section{Abrupt growth changes}

All trees belonging to the two groups ( $\mathrm{A}$ and $\mathrm{B}$ ) and to the three reference chronologies $(\mathrm{G}, \mathrm{S}$ and $\mathrm{T})$ present cores with abrupt growth changes. Nevertheless, in the period when at least $50 \%$ of cores from each group are present, trees growing on the glacier often show the highest mean percentage of cores per year presenting abrupt growth 
changes (Fig. 6). In the two glacier groups (A and B) and in the three control groups ( $\mathrm{T}, \mathrm{S}$ and $\mathrm{G})$, extreme growth releases $(>+70 \%)$ present higher percentages than extreme growth suppressions $(<-70 \%)$, but this is because the maximum growth releases also include variations higher than $+100 \%$, while growth reduction cannot be less than $-100 \%$ (when there is no growth, i.e. a missing ring).

Trees growing on the glacier present the highest mean percentages of extreme growth releases $>+70 \%$ : about $14 \%$ of cores per year with abrupt growth changes (Fig. 6). Also the cores of the reference $\mathrm{S}$ group show a quite high percentage $(8.0 \%)$ of cores per year demonstrating abrupt growth changes higher than $+70 \%$; this value is similar to that of the reference $\mathrm{T}$ group $(6.7 \%)$. Cores of the reference $\mathrm{G}$ group show the lowest value $(2.4 \%)$ in this growth variation interval.

Considering only the years where there are at least five cores and more than $25 \%$ of the total cores per group present growth variation higher than $+70 \%$, we obtained the following dates (Fig. 7): group A: 1988, 1989, 1990, 1993; group B: 1976, 1979, 1988, 1989, 1997; reference T: 1967, 1979, 1982; reference S: 1966, 1967, 1974, 1976, (1979; 23\%), 1987; reference G: 1960, 1979.

Year 1979 is a year in which a strong growth release should not be attributed to the movement of the glacier since it is also visible in the growth series of the reference groups outside the glacier ( $\mathrm{T}, \mathrm{S}$ and $\mathrm{G}$ ) which present positive abrupt growth change. The other dates found for the supraglacial trees could, however, be attributed to responses of trees to glacier movement. In particular, 1988 and 1989 could be years in which glacier movement occurred in both glacier lobes.

Supraglacial trees also demonstrate high frequencies of abrupt growth suppressions. Considering the cores manifesting growth suppression $(<-40 \%)$ in each group, we obtained the following significant years (Fig. 7): group A: 1985, 1997; group B: 1975, 1977, 1985, 1991, 2003; reference T: 1963, 1964, 1972, 1973; reference S: 1963, 1964, 1972, 1981; reference G: 1964, 1972, 1975.

Years 1963, 1964, 1972 present growth suppression in the reference growth series, but the sample size of the supraglacial trees is insufficient to make comparisons. Growth suppression in 1975 is especially evident in trees of group $B$ and the reference $G$ group.

\section{Event years}

The skeleton plot of each of the 52 samples supplied the identification of event years according to Schweingruber and others (1990), with particular regard to compression wood. Cross-dating with the reference chronologies allowed us to confirm the precise temporal attribution of the identified event years.

On the northern lobe (group A, Fig. 8a), despite the fact that few compression wood rings were detected, two precise periods were identified, 1990-92 and 2001-02, showing that these indicators are not casually distributed. With regard to the other types of indicators of growth disturbance (single, very narrow or wide tree rings, missing rings, rings with many resin ducts, eccentricity variations, abrupt growth changes), single trees reacted in different ways, mainly during the period 1989-98 (Fig. 8b).

On the southern lobe (group B, Fig. 8a) 45 more compression wood occurrences were identified. Their distribution partially follows tree cambial age (i.e. the number of

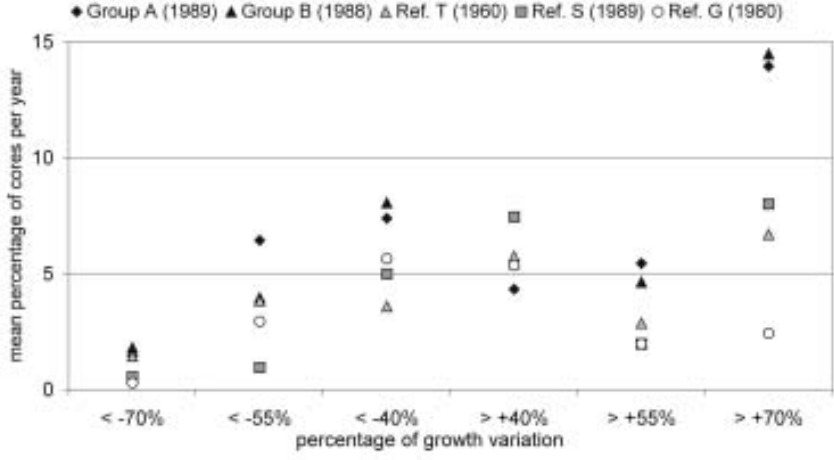

Fig. 6. Mean percentages of cores presenting abrupt growth changes in the considered growth variation intervals for all the groups (A, B and references). The percentages of growth variation are calculated with respect to the mean of the four previous years (see text). The numbers in parentheses indicate the first year of the considered period.

signals increases with the increase in sample depth), but some observations can be made:

1. in the period 1960-83, compression wood is practically absent, except in 1971 and 1974.

2. from 1984 until 2002 many event years occurred, with a high number of signals in 1985, 1988, 1992, 1993 and from 1995 to 2002, with a maximum value in 2001 .

The other growth anomalies are mainly concentrated in the period 1983-2003 (Fig. 8b), and some years correspond to years in which compression wood occurred (1985, 1988, 1997 and 2002).

\section{Summary of growth disturbance indicators}

Based on the results of our analysis of the tree-ring growth series and the visual assessment of the samples from the supraglacial tree-ring series, we constructed a timeline of events based upon the presence $(+1)$ /absence (0) of each type of growth disturbance indicator.

The years with higher scores are years in which many of the considered indicators are present (Fig. 9). On the northern lobe (Fig. 9a) there are five years with the simultaneous presence of at least two growth disturbance indicators: 1985, 1989, 1990, 1991 and 1993. On the southern lobe (Fig. 9b), ten years present more than three simultaneous growth disturbance indicators: 1984, 1985, 1986, 1988 (all four indicators), 1989, 1990, 1994, 1997, 2000 and 2002. Before 1984 the sample size is lower; nevertheless, it is possible to identify three years with at least two growth disturbance indicators: 1974, 1979 and 1981. The two graphs show a time-lag in the concentration of indicators. In the northern lobe they mainly occur in the period 1989-93 (5 years) and in the southern lobe in the period 1984-90 (7 years).

\section{Spatial distribution of event years}

The spatial distribution of the compression wood and of the other types of growth disturbance shows that the tree responses are scattered on the lobes (Fig. 10). The apparent concentration of signal on the internal border of the southern lobe is mainly due to the tree localization.

However, in some years precise disturbance localization can be noted. For example, in 1995 four trees located at the end of the southern lobe started to produce compression 

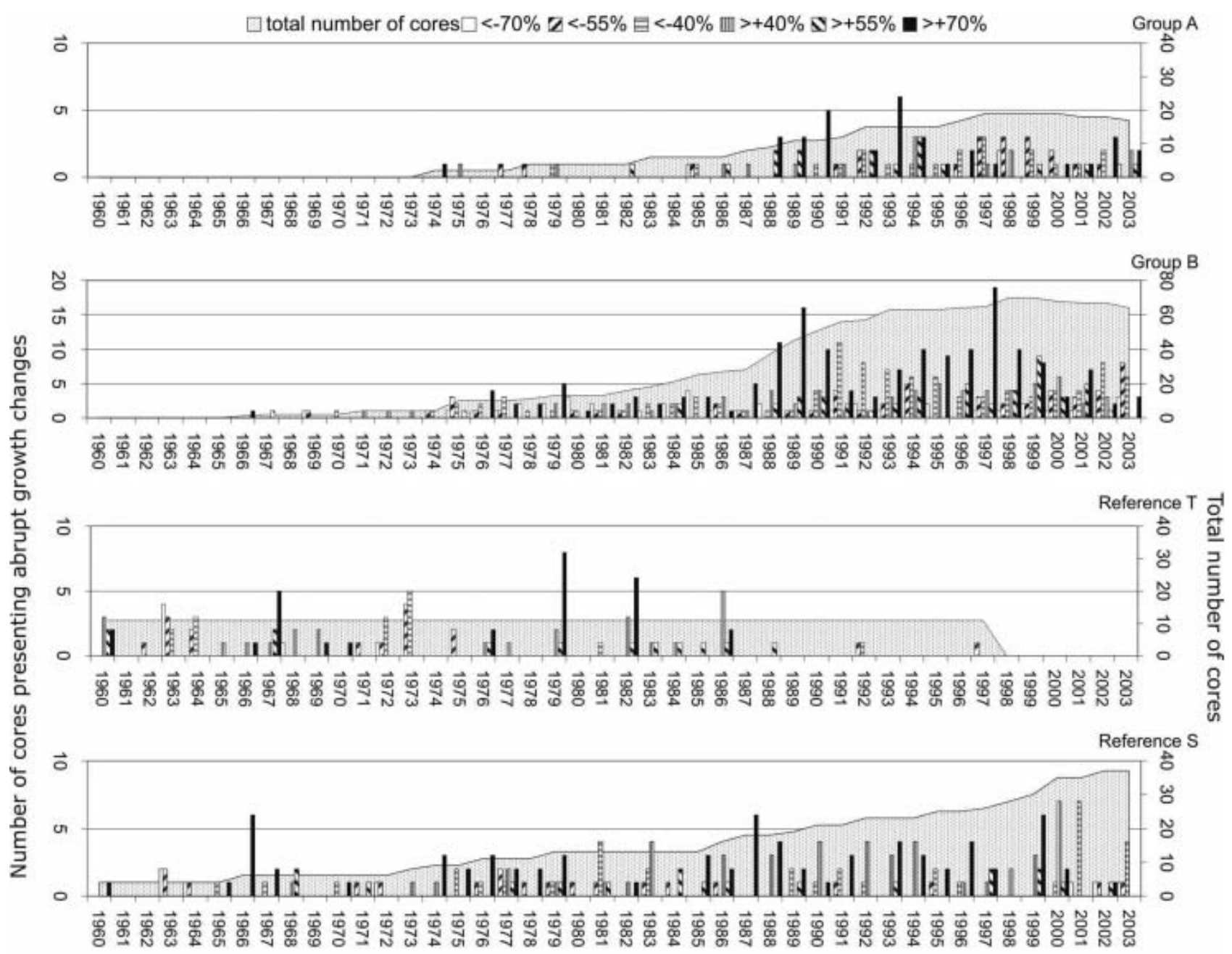

Reference G

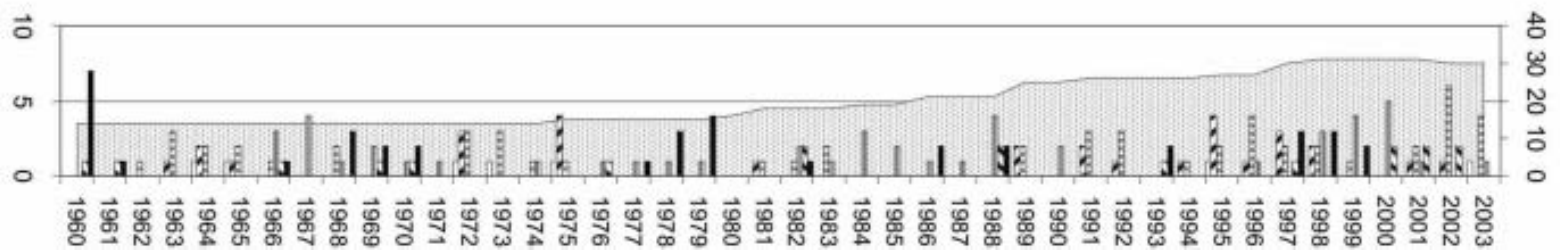

Fig. 7. Total number of cores presenting a strong growth change for each growth variation interval during the years 1960-2003. The total number of cores for each group is also shown. Note the different scales for group B. We can see how growth variations of $>+70 \%$ are more frequent than those of $<-70 \%$ for all the groups, and that in groups $A$ and $B$ these growth releases are more frequent than in references $\mathrm{T}$, S and $\mathrm{G}$.

wood. In 1997, some trees produced compression wood in the mid-part of the southern lobe, near the internal margin, and in the same year other types of growth disturbance are also present. This year is particularly significant because some trees on the lateral moraine (group C) were also tilted by the glacier pushing, thus producing compression wood (Fig. 11)

\section{DISCUSSION AND CONCLUSIONS}

Tree distribution on the glacier surface is not homogeneous. Its analysis indicated that areas characterized by more stable debris show more specimens, while the most unstable areas are not colonized, even if the debris thickness is similar. In particular morphological conditions such as small depressions and niches, vegetation probably finds better development conditions and shows more complex vegetation patterns. Field surveys indicate that most tree colonization takes place only where the thickness exceeds $40 \mathrm{~cm}$. Therefore, the local absence of supraglacial trees can give information about the presence of shallow debris layers or great debris instability. A similar situation is documented, for example, on the external part of the two lobes, where trees are absent and the rapid evolution of the glacier is revealed by the presence of small swallow holes. Moreover, since rockfalls from the high surrounding peaks frequently occur (Giardino and others, 2001), the local thickness increase of the debris layer could be related to the progressive distribution of landslide deposits along the glacier tongue and outlined by the local concentration of trees.

The distribution of the cambial age in the supraglacial trees is problematic. Along the glacier, trees become rapidly younger with increase in elevation, whereas on the surrounding slopes large and old trees (i.e. specimens used for 


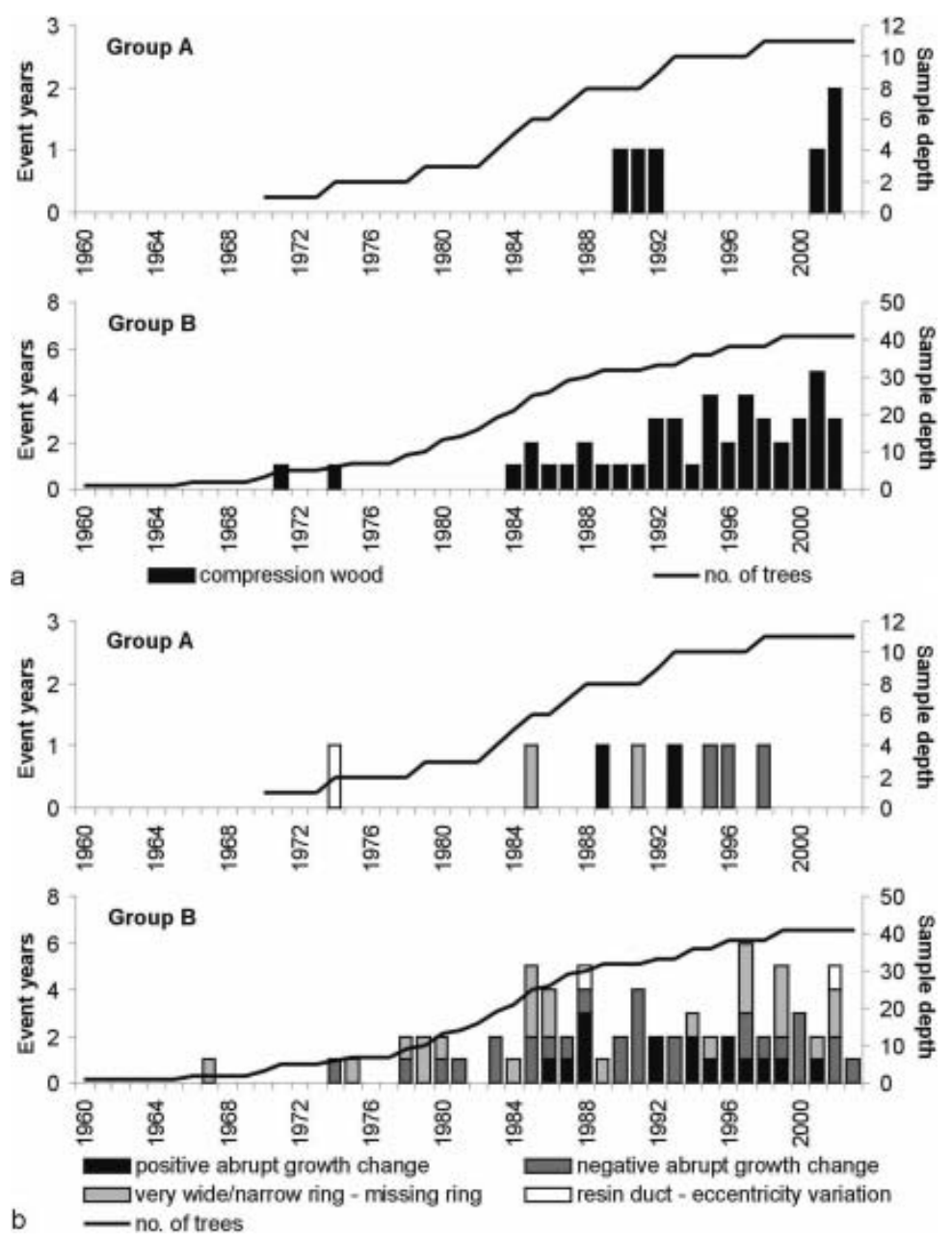

Fig. 8. Event years ((a) compression wood and (b) other growth anomalies) identified by skeleton plots of supraglacial trees on the northern lobe (group A) and southern lobe (group B).

reference chronology $\mathrm{T}$ that date back to the 17 th century) can frequently be found up to the tree line. The presence of very young trees near their upper limit can again be related to the shallowness of the debris layer and to the higher instability of the supraglacial debris.
The current spatial distribution of trees does not show the pattern at the moment of their germination. As a result of the glacier flow, tree localization is further up-valley. The reconstructed original position of trees does not exceed the origin of the southern lobe, where today no trees grow.

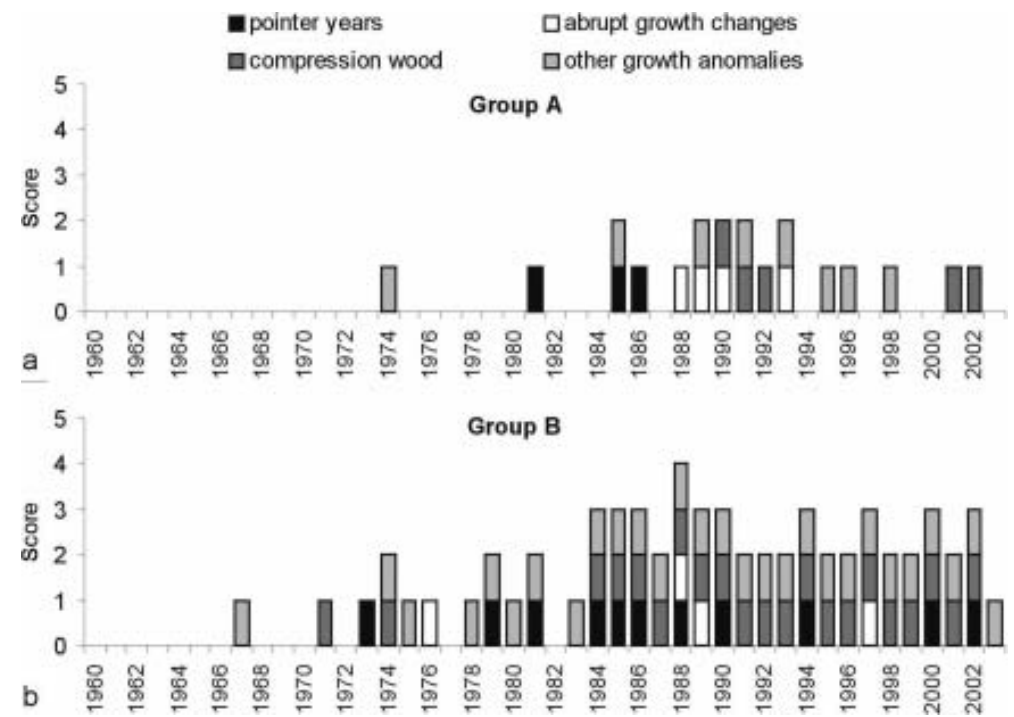

Fig. 9. Time distribution summary of the growth disturbance indicators. 


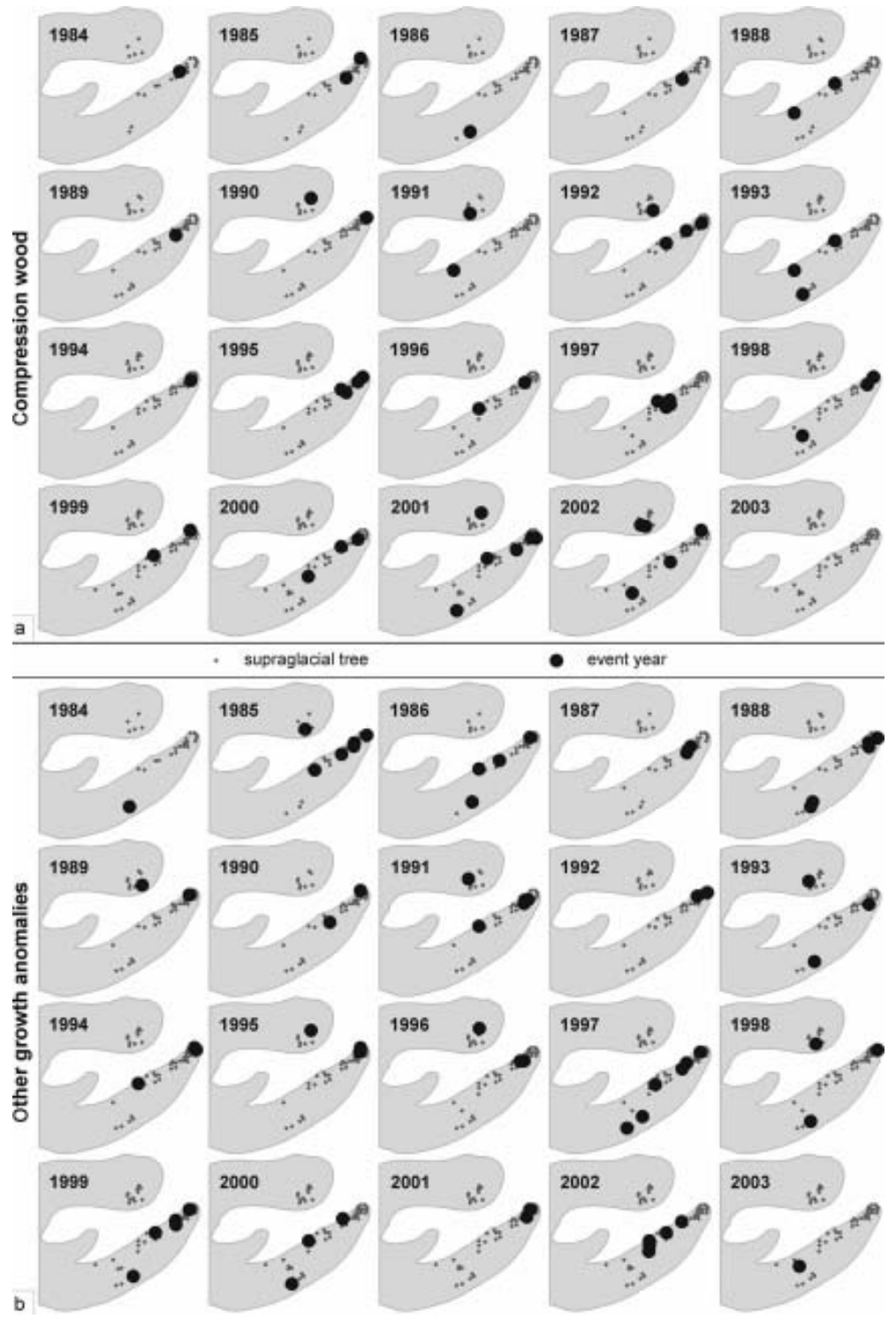

Fig. 10. Spatial distribution of (a) compression wood and (b) other growth anomalies, since 1984. Previous years were omitted because of the low number of samples and event years. The position of trees on the map corresponds to the localization at the sampling time (2004).

The present position of trees confirms the mean surface velocity value derived from the literature.

Concerning the time distribution of growth disturbance indicators, the lack of signals before the beginning of the 1980s and their later concentration can be observed. Aerial photographs taken in 1975 and 1988 (Giardino and others, 2001) document the growing phase of the glacier tongue, also investigated by Thomson and others (2000). The photographs show that Miage glacier rapidly changed between these years, as the frontal lobes were concave in 1975 and convex in 1988, demonstrating a significant mass change. The tongue deformation firstly induced an upheaval of the trees, then a lowering of the surface, with probable changes in their position and possible disturbance to their growth due to surface instability. The growth disturbance signals have mainly occurred since the mid-1980s on the southern lobe and at the beginning of the 1990s on the northern lobe, with a delay of about 5 years. The occurrence of these indicators suggests that the trees on the southern lobe reacted to a variation in substrate stability before the trees on the northern lobe. Thus, the glacier kinematic wave could have reached the southern lobe first and the northern lobe a few years later. Moreover, the disturbance lasts for 7 years on the southern lobe and for 5 years on the northern lobe. The time-lag and the time span suggest that the kinematic wave which crossed the glacier tongue in the 1980s (Giardino and others, 2001) may have been slower and weaker on the northern lobe.

Some of the years identified as indicators of glacier or debris instability can be related to particular climatic or environmental conditions. An example is the year 1997, when both supraglacial trees (group B) and trees on the inner lateral moraine (group C) were damaged (Fig. 11). In fact, a strong flood occurred throughout Valle d'Aosta in 1996. In particular, intense precipitation occurred during 23 and 24 July in Val Veny and in Val Ferret, causing a strong increase in stream discharge to the point of locally breaking their banks (Bonetto and others, 1998). It is possible that the overland flow was strong everywhere and affected the glacier as well, thus changing water availability and increasing the movements of the surface debris in relation to the ablation rate of the ice below. In this case, growth disturbances were found in the tree rings of 1997, i.e. just 1 year later. This situation usually occurs because at the end 


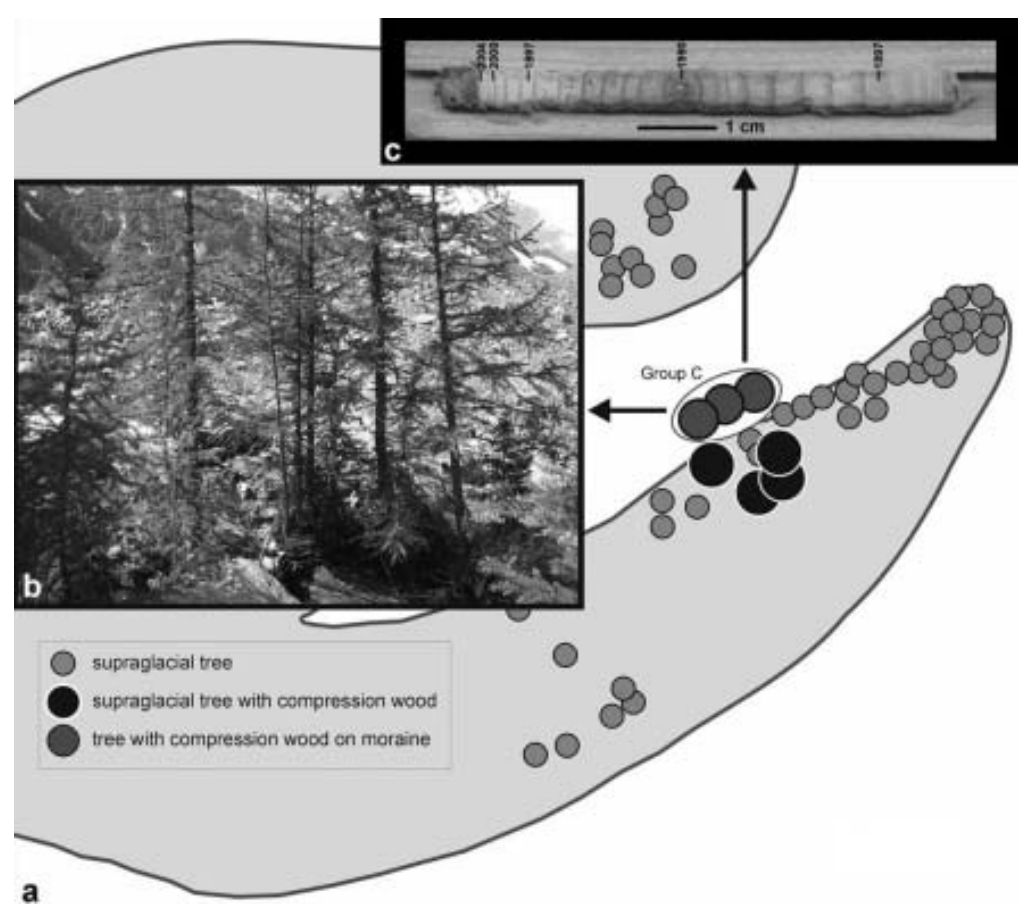

Fig. 11. Detail for the year 1997 when both trees on the glacier and on the inner lateral moraine (group C) started to produce compression wood (from Pelfini and others, 2005, modified).

of July the growth season comes to an end at this altitude. Therefore, tree responses can only be found in the following ring (Corominas and Moya, 1999).

The growth anomalies analyzed in this paper, particularly compression wood, correspond to the response of the trees to environmental conditions around them and represents a helpful method of localizing and dating glacier superficial movements. Sometimes it is difficult not only to determine the triggering causes, but also to interpret the high variability in the growth trend of very young trees that can affect the reliability of cross-dating with reference chronologies. Nevertheless, this research carried out on Miage glacier shows for the first time, at least for the Italian Alps, the relation between tree growth disturbance and pulses of increased mass flux (kinematic waves).

\section{ACKNOWLEDGEMENTS}

This research was co-funded by the Ministero Istruzione Università, Ricerca (MIUR) Cofin 2004 project 'The geomorphological heritage as a resource for a sustainable tourism' (National Coordinator: M. Panizza; Local Chief Researcher: M. Pelfini) and by the MIUR Cofin 2005 project 'Increasing rate of climate change impacts on high mountain areas: cryosphere shrinkage and environmental effects' (National and Local Coordinator: C. Smiraglia). We acknowledge C. Smiraglia for scientific suggestions, D. Brioschi and P. Bertoglio for their contribution in collecting data, Regione Autonoma Valle d'Aosta for sampling authorization and Cabina di Regia dei Ghiacciai Valdostani. We also thank H. Davies for revising the English.

\section{REFERENCES}

Baretti, M. 1880. II Ghiacciaio del Miage. Versante italiano del gruppo del monte Bianco (Alpi Pennine). Mem. Reale Accad. Sci. Torino, 2, 2-36.
Benn, D.I. and D.J.A. Evans. 1998. Glaciers and glaciation. London, Arnold.

Bonetto, F., G. Cesti and M. Montel. 1998. L'alluvione del 24 luglio 1996 nell'alta Valle d'Aosta. Nimbus 13-14, 126-129.

Carrer, M. and C. Urbinati. 2004. Age-dependent tree-ring growth responses to climate in Larix decidua and Pinus cembra. Ecology, 85(3), 730-740.

Carrer, M. and C. Urbinati. 2006. Long-term change in the sensitivity of tree-ring growth to climate forcing in Larix decidua. New Phytol., 170(4), 861-872.

Coratza, P. and C. Giusti. 2005. Methodological proposal for the assessment of the scientific quality of geomorphosites. II Quaternario, Ital. J. Quat. Sci., 18(1), 307-313.

Corominas, J. and J. Moya. 1999. Reconstructing recent landslide activity in relation to rainfall in the Llobregat River basin, Eastern Pyrenees, Spain. Geomorphology, 30(1-2), 33-52.

Deline, P. 2002. Etude géomorphologique des interactions écroulements rocheux/glaciers dans la haute montagne alpine (versant sud-est du massif du Mont Blanc). (PhD thesis, Université de Savoie.)

Deline, P. and G. Orombelli. 2005. Glacier fluctuations in the western Alps during the Neoglacial, as indicated by the Miage morainic amphitheatre (Mont Blanc massif, Italy). Boreas, 34(4), 456-467.

Diolaiuti, G., M.P. Kirkbride, C. Smiraglia, D.I. Benn, C. D'Agata and L. Nicholson. 2005a. Calving processes and lake evolution at Miage glacier, Mont Blanc, Italian Alps. Ann. Glaciol., 40, 207-214.

Diolaiuti, G., C. Smiraglia, M. Pelfini, C. D'Agata and M. Caccianiga. 2005b. Natural assets in glacialized areas and the use of GIS for the valorization of high mountain regions. I/ Quaternario, Ital. J. Quat. Sci., 18(1), 275-283.

Fleisher, P.J., M.S. Lachniet, E.H. Muller and P.K. Bailey. 2006. Subglacial deformation of trees within overridden foreland strata, Bering Glacier, Alaska. Geomorphology, 75(1-2), 201-211.

Frank, D. and J. Esper. 2005. Characterization and climate response patterns of a high-elevation, multi-species tree-ring network in the European Alps. Dendrochronologia, 22(2), 107-121.

Fritts, H.C. 1976. Tree rings and climate. London, Academic Press. 
Giardino, M., G. Mortara and F. Bonetto. 2001. Proposta per la realizzazione di un catalogo aerofotografico dei ghiacciai italiani. Suppl. Geogr. Fis. Din. Quat. 5, 89-98.

Gutsell, S.L. and E.A. Johnson. 2002. Accurately ageing trees and examining their height-growth rates: implication for interpreting forest dynamics. J. Ecol., 90(1), 153-166.

Holmes, R.L. 1983. Computer-assisted quality control in tree-ring dating and measurement. Tree-Ring Bull., 43(1), 69-78.

Holzhauser, H. and H.J. Zumbuhl. 1999. Glacier fluctuations in the Western Swiss and French Alps in the 16th century. Climatic Change, 43(1), 223-237.

Huber, B. and V. Giertz-Siebenlist. 1969. Unsere tausendjährige Eichen-Jahrringchronologie, durchschnittlich 57-(10-50-)fach belegt. Akad. Wiss. Wien, Math-Naturwiss. Kl., Sitzungber., 178( $\mathrm{H} 1-4), 37-42$.

Hüsken, W. and W. Schirmer. 1993. Drei Jahrringchronologien aus den Pragser Dolomiten/Südtirol. Dendrochronologia, 11, 123-137.

Josza, L. 1988. Increment core sampling techniques for high quality cores. Vancouver, BC, Forintek Canada Corp. (Special Publication SP-30.)

Kaiser, K.F. 1993. Growth rings as indicators of glacier advances, surges and floods. Dendrochronologia, 11, 101-122.

Körner, C. and G. Hoch. 2006. A test of treeline theory on a Montane permafrost island. Arct. Antarct. Alp. Res., 38(1), 113-119.

Larocque, S.J. and D.J. Smith. 2005. 'Little Ice Age' proxy glacier mass balance records reconstructed from tree rings in the $\mathrm{Mt}$ Waddington area, British Columbia Coast Mountains, Canada. Holocene, 15(5), 748-757.

Lesca, C. 1974. Emploi de la photogrammétrie analytique pour la détermination de la vitesse superficielle des glaciers et des profondeurs relatives. Boll. Com. Glac. Ital., 22, 169-186.

Luckman, B.H. 1996. Dendrochronology at Peyto Glacier, Alberta. In Dean, J.S., D.S. Meko and T.W. Swetnam, eds. Tree rings, Environment and Humanity: Proceedings of the International Conference, Tucson, Arizona, 17-21 May, 1994. Tucson, AZ, Radiocarbon, 679-688.

Luckman, B.H. 2000. The Little Ice Age in the Canadian Rockies. Geomorphology, 32(3-2), 357-384.

Nicolussi, K. 1994. Jahrringe und Massenbilanz: dendroklimatologische Rekonstruktion der Massenbilanzreihe des Hintereisferners bis zum Jahr 1400 mittels Pinus cembra-Reihen aus den Ötztaler Alpen. Z. Gletscherkd. Glazialgeol., 30, 11-52.

Panizza, M. 2001. Geomorphosites: concepts, methods and examples of geomorphological surveys. [Chinese Sci. Bull.], 46(Part Supp.), 4-6.

Panizza, M., ed. 2005. Manuale di geomorfologia applicata. Milan, Franco Angeli s.r.l.

Panizza, M. and S. Piacente. 1989. Geomorphological assets evaluation. Z. Geomorphol., Supplementband 87, 13-18.

Pelfini, M. 1999. Dendrogeomorphological study of glacier fluctuations in the Italian Alps during the Little Ice Age. Ann. Glaciol., 28, 123-128.

Pelfini, M. 2003. Il contributo della dendrocronologia alla ricostruzione delle fluttuazioni glaciali degli ultimi secoli. In Biancotti, A. and M. Motta, eds. Risposta dei processi geomorfologici alle variazioni ambientali. Genoa, Glauco Brigati, 327-344.
Pelfini, M. and C. Smiraglia. 2003. I ghiacciai, un bene geomorfologico in rapida evoluzione. Boll. Soc. Geogr. Ital., XI(VIII), $521-544$

Pelfini, M., M. Bozzoni and M. Santilli. 2005. Il Ghiacciaio del Miage: un geosito dalla peculiare valenza ecologica. SLM, Sopra il livello del mare 23, 8-15.

Richter, M., T. Fickert and F. Grüninger. 2004. Pflanzen auf schuttbedeckten Gletschern - wandernde Kuriositäten. Geoöko [Bensheim], 25(3/4), 225-256.

Rinn, F. 1996. TSAP: time series analysis and presentation. Reference manual. Version 3.0. Heidelberg, Frank Rinn Engineering and Distribution.

Rolland, C., W. Baltensweiler and V. Petitcolas. 2001. The potential for using Larix decidua ring widths in reconstructions of larch budmoth (Zeiraphera diniana) outbreak history: dendrochronological estimates compared with insect surveys. Trees, 15(7), 414-424.

Sacco, F. 1917. L'apparato morenico del Ghiacciaio del Miage. Boll. Soc. Geol. Ital., 36, 323-354.

Saussure, H.-B. de. 1774. Voyage autour du Mont Blanc en 1774 10 juil. Brouillard en crayon. Manuscript 14/1. BPU Genève.

Saussure, H.-B. de. 1786. Voyages dans les Alpes, précédés d'un essai sur l'histoire naturelle des environs de Genève. Vol. 2. Geneva, Barde, Manguet \& Compagnie.

Schweingruber, F.H. 1986. Abrupte Zuwachsschwankungen in Jahrringabfolgen als ökologische Indikatoren. Dendrochronologia, 4, 125-183.

Schweingruber, F.H. 1988. Tree rings: basics and applications of dendrochronology. Dordrecht, etc., D. Reidel.

Schweingruber, F.H. 1996. Tree rings and environment: dendroecology. Berne, Paul Haupt.

Schweingruber, F.H., D. Eckstein, F.S. Bachet and U.O. Brächer. 1990. Identification, presentation and interpretation of event years and pointer years in dendrochronology. Dendrochronologia, 8, 3-39.

Schweingruber, F.H., U. Wehrli, K. Aellen-Rumo and M. Aellen. 1991. Weiserjahre als Zeiger extremer Standorteinflüsse. Schweiz. Z. Forstwes., 142, 33-52.

Smiraglia, C., G. Diolaiuti, D. Casati, and M.P. Kirkbride. 2000. Recent areal and altimetric variations of Miage Glacier (Monte Bianco massif, Italian Alps). IAHS Publ. 264 (Symposium at Seattle 2000 - Debris-Covered Glaciers), 227-233.

Thomson, M.H., M.P. Kirkbride, and B.W. Brock. 2000. Twentieth century surface elevation change of the Miage Glacier, Italian Alps. IAHS Publ. 264 (Symposium at Seattle 2000 - DebrisCovered Glaciers), 219-225.

Timell, T.E. 1986. Compression wood in gymnosperms. Berlin, Springer-Verlag.

Watson, E. and B.H. Luckman. 2004. Tree-ring-based mass-balance estimates for the past 300 years at Peyto Glacier, Alberta, Canada. Quat. Res., 62(1), 9-18.

Z'Graggen, S. 1987. Dendrocronologia e moria del bosco nella regione alpina. In Istituto Italiano di Dendrocronologia, ed. Atti del Convegno Dendrocronologia e moria del bosco in Europa, Verona, 10 October 1986. Verona, Istituto Italiano di Dendrocronologia, 21-31. 